\title{
JUSTIFICATION OF MAIN DESIGN PARAMETERS OF ASYNCHRONOUS ELECTRIC MOTOR CURRENT PROTECTION
}

\author{
Victor Petko, Ilmira Rakhimzhanova, Yuriy Ushakov, Maxim Fomin, Valery Kononets \\ Orenburg State Agrarian University, Russia \\ srvg1982@rambler.ru, ahmetova_i@mail.ru,1u6j1a159@mail.ru,mbfom@mail.ru
}

\begin{abstract}
The article considers the issues of current protection circuitry of asynchronous motors operating from the AC mains of standard frequency. It is noted that in the vast majority of cases transformer current sensors operating in idle mode (transreactors) or in short circuit mode (current transformers) are used as current sensors in such protections. Current transformers have a more stable linear "input-output" characteristic, less current and angular errors, so they are most widespread. The purpose of the work is to substantiate the parameters of the universal current transformer and methods of setting setpoint currents for the protection unit of asynchronous motors having a wide range of rated currents. It is shown that nominal currents of protection units for different groups of electric motors with the multiplicity of the maximum to the minimum nominal currents equal to four will be determined only by the number of turns and the section of the primary winding installed in each specific unit of the current transformer. Moreover, with the maximum possible nominal current for a particular design of the protection unit, which allows direct switching into the controlled current circuit without intermediate current transformers, the number of turns of the primary winding should be equal to one. Under these conditions, it is technically possible to change the nominal current of the current protection device by changing the number of turns of the primary winding of current transformers with a discrete coefficient equal to 2:1 turns, 2 turns, 4 turns, 8 turns, etc. At the same time, it is proposed to set the actuation current of the protection unit for each specific motor by discrete change in the conductivity of the load included in the secondary winding of the current transformer.
\end{abstract}

Keywords: current transformer, transreactor, setter, size, discreteness.

\section{Introduction}

Electric drive of machines and mechanisms in the overwhelming majority of cases is carried out on the basis of a wide range of three-phase asynchronous electric motor (EM) capacities with a squirrelcage rotor voltage of 220/380 volts [1]. When designing induction motors, it is necessary to ensure that their characteristics meet the requirements of the technical specifications and current standards [2]. A typical example of such electric drives is the electric drive of submersible electric pumps of various capacities in the of industrial and domestic consumers' water supply systems [3-5]. In [6;7] it is shown that the flow of a transient process during a short circuit, or switching on the EM in the network, disconnecting it from the network, changes in the supply voltage, etc., what corresponds to a set of steady-state modes when the stator is supplied with a nominal AC voltage and nominal frequency but at different rotor slip. They are completed with power stations equipped with overcurrent protection units $[8 ; 9 ; 10 ; 11]$, the size of which must correspond to the protected electric motors' operating current [12]. Basically, transformer current sensors are used as current sensors in such protections, since, in addition to the measuring function, they perform the function of galvanic isolation of power circuits and control circuits [13]. Such protection standard size is mainly determined only by the parameters of the transformer current sensor primary winding, while the parameters of their threshold and logical parts for all standard sizes are practically the same. The range of current settings for each standard size range is set in this case by the number of turns of the of the current sensor's primary winding.

The purpose of this work is to substantiate the standard-size range of current protections of this type.

\section{Materials and methods}

The series of nominal indicators (characteristics) of electrical apparatus, devices and their elements are usually represented by a numerical sequence of the form of geometric progress, which any of members

$$
a_{\mathrm{i}}=a_{0} q^{i},
$$

where $i$ - any positive or negative integer;

$a_{0}-$ geometric progression initial term;

$q$-progression coefficient. 
It is convenient to take 1 as the initial term of the series and take the value of the coefficient $q$ equal to $\sqrt[k]{10}$. Then for $k=3$ we have the series $\mathrm{R} 3$, for $k=5-$ the series R5, etc. (Table 1,2).

Table 1

Scale of rated currents for $\mathrm{R5}$ series

\begin{tabular}{|c|c|c|c|c|c|c|c|c|c|c|c|}
\hline$j / m$ & $j$ & 0 & & 1 & & 2 & & 3 & & 4 & \\
\hline$m$ & & \multicolumn{10}{|c|}{$a_{m j}$} \\
\hline$\ldots$ & \multirow{6}{*}{$a a_{m j}$} & $\ldots$ & $\ldots$ & $\cdots$ & $\ldots$ & $\ldots$ & $\ldots$ & $\cdots$ & $\ldots$ & $\ldots$ & $\cdots$ \\
\hline 2 & & $\begin{array}{l}a_{20=} \\
100\end{array}$ & & $\begin{array}{c}a_{21}= \\
125.89\end{array}$ & & $\begin{array}{c}a_{22}= \\
158.49\end{array}$ & & $\begin{array}{l}a_{2}= \\
200\end{array}$ & & $\begin{array}{c}a_{24}= \\
251.2\end{array}$ & \\
\hline 1 & & $\begin{array}{c}a_{10=} \\
10\end{array}$ & & $\begin{array}{c}a_{11}= \\
12.589\end{array}$ & & $\begin{array}{c}a_{12}= \\
15.849\end{array}$ & & $\begin{array}{l}a_{13}= \\
20.0\end{array}$ & & $\begin{array}{c}a_{14}= \\
25.12\end{array}$ & \\
\hline 0 & & $\begin{array}{c}a_{00}= \\
1\end{array}$ & & $\begin{array}{c}a_{01}= \\
1.2589\end{array}$ & & $\begin{array}{c}a_{02}= \\
1.5849\end{array}$ & & $\begin{array}{l}a_{03}= \\
2.00\end{array}$ & & $\begin{array}{c}a_{04}= \\
2.512\end{array}$ & \\
\hline-1 & & $\begin{array}{c}a_{-11}= \\
0.1\end{array}$ & & $\begin{array}{c}a_{-11=} \\
0.126\end{array}$ & & $\begin{array}{c}a_{-12=} \\
0.1585\end{array}$ & & $\begin{array}{l}a_{-13}= \\
0.200\end{array}$ & & $\begin{array}{c}a_{-14}= \\
0.2512\end{array}$ & \\
\hline$\ldots$ & & $\ldots$ & $\ldots$ & $\ldots$ & $\ldots$ & $\ldots$ & $\ldots$ & $\ldots$ & $\ldots$ & $\ldots$ & $\ldots$ \\
\hline
\end{tabular}

Scale of rated currents for $\mathrm{R} 10$ series

Table 2

\begin{tabular}{|c|c|c|c|c|c|c|c|c|c|c|c|}
\hline$j / m$ & $j$ & $\mathbf{0}$ & & 1 & & 2 & & 3 & & 4 & \\
\hline$m$ & & \multicolumn{10}{|c|}{$a_{m j}$} \\
\hline$\ldots$ & & $\ldots$ & $\ldots$ & $\ldots$ & $\ldots$ & $\ldots$ & $\ldots$ & $\ldots$ & $\ldots$ & $\ldots$ & $\ldots$ \\
\hline 2 & & $\begin{array}{c}a_{20}= \\
100\end{array}$ & $\begin{array}{c}a_{21}= \\
125.9\end{array}$ & $\begin{array}{c}a_{22}= \\
158.49\end{array}$ & $\begin{array}{l}a_{2=} \\
200\end{array}$ & $\begin{array}{c}a_{24}= \\
251.2\end{array}$ & $\begin{array}{c}a_{25}= \\
316.2\end{array}$ & $\begin{array}{c}a_{26}= \\
398.1\end{array}$ & $\begin{array}{c}a_{27}= \\
501.2\end{array}$ & $\begin{array}{c}a_{28}= \\
631.0\end{array}$ & $\begin{array}{c}a_{29}= \\
794.3\end{array}$ \\
\hline 1 & & $\begin{array}{c}a_{10}= \\
10\end{array}$ & $\begin{array}{l}a_{111}= \\
12.59\end{array}$ & $\begin{array}{c}a_{12}= \\
15.849\end{array}$ & $\begin{array}{l}a_{13}= \\
20.0\end{array}$ & $\begin{array}{c}a_{14}= \\
25.12\end{array}$ & $\begin{array}{c}a_{15}= \\
31.62\end{array}$ & $\begin{array}{c}a_{16}= \\
39.81\end{array}$ & $\begin{array}{c}a_{17}= \\
50.12\end{array}$ & $\begin{array}{c}a_{18}= \\
63.10\end{array}$ & $\begin{array}{c}a_{19}= \\
79.43\end{array}$ \\
\hline 0 & & $\begin{array}{c}a_{00}= \\
1\end{array}$ & $\begin{array}{l}a_{01}= \\
1.259\end{array}$ & $\begin{array}{c}a_{02}= \\
1.5849\end{array}$ & $\begin{array}{l}a_{03}= \\
2.00\end{array}$ & $\begin{array}{c}a_{04}= \\
2.512\end{array}$ & $\begin{array}{c}a_{05}= \\
3.162\end{array}$ & $\begin{array}{c}a_{06}= \\
3.981\end{array}$ & $\begin{array}{c}a_{07}= \\
5.012\end{array}$ & $\begin{array}{l}a_{08}= \\
6.310\end{array}$ & $\begin{array}{c}a_{09}= \\
7.943\end{array}$ \\
\hline-1 & & $\begin{array}{c}a_{-11}= \\
0.1\end{array}$ & $\begin{array}{l}a_{-11}= \\
0.126\end{array}$ & $\begin{array}{c}a_{-12=} \\
0.1585\end{array}$ & $\begin{array}{l}a_{-13}= \\
0.200\end{array}$ & $\begin{array}{c}a_{-14}= \\
0.2512\end{array}$ & $\begin{array}{c}a_{-15}= \\
0.3162\end{array}$ & $\begin{array}{c}a_{-16}= \\
0.3981\end{array}$ & $\begin{array}{c}a_{-17}= \\
0.5012\end{array}$ & $\begin{array}{c}a_{-18}= \\
0.6310\end{array}$ & $\begin{array}{l}a_{-19=} \\
0.794\end{array}$ \\
\hline$\ldots$ & & $\ldots$ & $\ldots$ & $\ldots$ & $\ldots$ & $\ldots$ & $\ldots$ & $\ldots$ & $\ldots$ & $\ldots$ & $\ldots$ \\
\hline
\end{tabular}

If we submit the number $i$ as equal to $m k+j$, where $j=1,2, \ldots(k-1)$, and $m$ is a positive or negative integer, then the $i$-th term of the series

$$
a_{i}=1 \cdot q^{i}=q^{m k+j}=q^{j}\left(q^{k}\right)^{m}=q^{j} \cdot 10^{m}=a_{j} \cdot 10^{m},
$$

where $a_{j}-j$ - th term of the part of the RK series, lying in the range from 1 to 10 .

Currently, in electrical engineering, the scale of rated currents (powers) of power devices and equipment in accordance with GOST 6827-76 [14] corresponds to the R5 series $\left(q_{R 5}=\sqrt[5]{10}=1.585\right)$ or the R10 series $\left(q_{R 10}=\sqrt[10]{10}=1.259\right)$.

Due to the fact that the current protection rated current unit is mainly determined by the primary winding rated current of the transformer current sensor installed in it, it can be changed by changing its primary winding number of turns and the section. Moreover, for current protection number of standard sizes, covering current range controlled by them, within which direct (without intermediate current 
transformers) connection of the sensor primary winding into the controlled current circuit is allowed, it should be minimal. In particular, for a current protection unit designed for the maximum current in the monitoring range, it should be equal to one. It follows from the condition of minimizing the sensor's dimensions and the voltage loss in the circuit of the phase windings of the protected EM. Then, it is technically possible to change the current protection unit's rated current by changing the number of turns of the primary winding with a discreteness factor equal to 2 ( 1 turn, 2 turns, 4 turns, etc.).

Therefore, for over current protection units of this type, a number of rated currents will be obtained (we denote it by the symbol R1), in which $q_{R 1}=\sqrt[1]{2}=2$, and the $n$-th term

$$
a_{n}=a_{0} \cdot 2^{n} .
$$

In this case, the value of this series' initial term $a_{0}$ should be such that the series' one of the members would be equal to $5 \mathrm{~A}$. Then the current protection unit for a rated current of $5 \mathrm{~A}$ from this series can also be used in stations with other (large) rated currents, including them into the circuit of the protected EM through standard current transformers, in which the value of the secondary current is $5 \mathrm{~A}$. It is practically indifferent which of the resulting series' members will be taken as the initial one. This only affects the degree of formula use (2). Consequently, taking into account the fact that EM in power technological devices with a rated current much less than $5 \mathrm{~A}$ are used very rarely, it is advisable to take exactly $5 \mathrm{~A}$ for the initial current value of the current protection smallest standard-size version. Then the $\mathrm{n}$-th term of the series $\mathrm{R} 1$

$$
a_{n}=5 \cdot 2^{n}=(5,10,20,40 \text {, etc. }) .
$$

It is important to determine whether the members of this series correspond to any members of the R10 series, provided that the initial members of these series are the same and equal to 5. In accordance with this, we can write

$$
a_{n}=a_{\mathrm{i}}=5 \cdot 2^{n}=5 \cdot\left(10^{1 / 10}\right)^{i} \text {, or } 2=\left(10^{1 / 10}\right)^{i / n}, \text { where from } i / n \approx 3 .
$$

This means that each term of the binary series is approximately equal to each third term of the decimal series (see Table 3), obtained by calculation by formulas (1) and (2), and is exactly equal to each third term of the standard decimal series of currents. That is, the R1 series fits completely into the R10 series. Such a mutual correspondence of the rows opens up the possibility of equipping stations made at any of the rated currents in the R1 row with power devices with rated currents from the R10 row.

\begin{tabular}{|c|c|c|c|c|c|c|c|c|c|c|c|c|c|c|}
\hline \multirow{3}{*}{ R10 } & $i$ & 0 & 1 & 2 & 3 & 4 & 5 & 6 & 7 & 8 & 9 & 10 & 11 & 12 \\
\hline & $I_{\mathrm{P}}, \mathrm{A}$ & 5 & 6.3 & 7.9 & 9.98 & 12.6 & 15.8 & 19.9 & 25 & 31.5 & 39.7 & 50 & 63 & 79.2 \\
\hline & $I_{\mathrm{C}}, \mathrm{A}$ & 5 & 6.3 & 8 & 10 & 12.5 & 16 & 20 & 25 & 31.5 & 40 & 50 & 63 & 80 \\
\hline \multirow{2}{*}{ R1 } & $I, \mathrm{~A}$ & 5 & - & - & 10 & - & - & 20 & - & - & 40 & - & - & 80 \\
\hline & $n$ & 0 & & & 1 & & & 2 & & & 3 & & & 4 \\
\hline
\end{tabular}

Table 3

\section{Rated currents from series E10 and D1}

Each specific station, equipped with an over current protection unit with a rated current equal to one of the values of the R1 series $\left(I_{n}=5 \cdot 2^{n}\right)$, must cover the operating currents zone (the zone for adjustment of the current protection settings), at least in the range from $I_{n}$ to $\left.I_{n-1}\right)$. Then, for protected electric motors' any range, it is possible to select a station corresponding to it in terms of current from the standard-size range R1. However, in order to avoid difficulties when choosing a station for an EM with a rated current close to the border of the operating currents of two neighbouring stations in a standard-sized row, their operating current zones (the zone of changing the current of the settings $\Delta I y$ ) of each specific station should overlap each other.

In the conditions of dispersed electrical equipment and its insufficient nomenclature (first of all, it refers to agro-industrial production), it is sometimes necessary to complete the protected EM with oversized stations. Such typical example is the maintenance and repair of electric motors of water supply system submersible pumps, which are carried out by mobile teams, which often do not have preliminary information about the electric motor capacities, requiring the replacement of a failed one or the installation of a new control station. So that even with an overestimated rated power, the station can be 
tuned to the current of the protected EM, it is advisable to extend the zone of changing the settings of its current protection to the range from $I_{n}$ to $I_{n-2}$, that is, to ensure double overlap of the rated currents of the R1 series. Then, for each EM of a certain power, there will be two options for equipping it with a control station: the main one, when the EM current value falls into the zone of the station operating currents in the range from $I_{n-1}=0.5 I_{n}$ to $I_{n}$, and the permissible (spare), when the EM current value lies in the range from $I_{n-2}=0.25 I_{n}$ to $I_{n-1}=0.5 I_{n}$ (see Fig. 1).

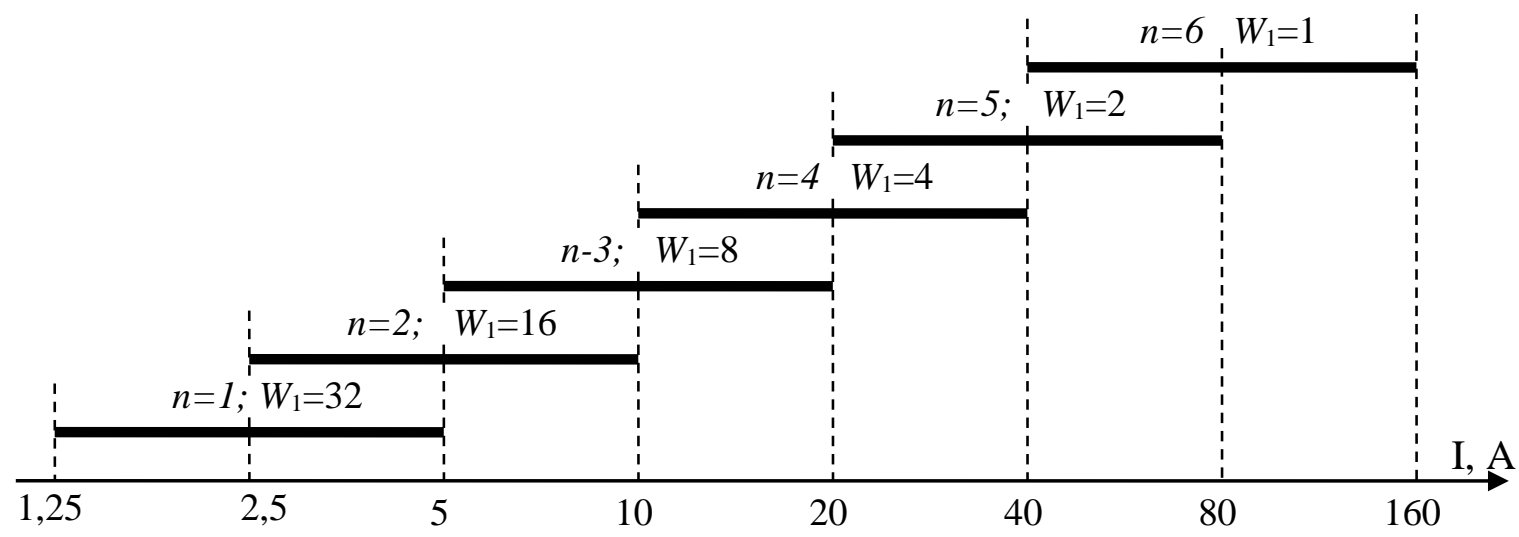

Fig. 1. Changing setting zones of the measuring part of current protection starting from the first standard size $\boldsymbol{W}_{1}=1$ to the sixth standard size $\left(\boldsymbol{W}_{1}=32\right)$

It is impractical to expand the operating current range of one and the same station by more than 1:4, since this will lead to underutilization of the station"s installed power at low, compared to its nominal power, the power of the protected EM, as well as the need to use a multi-limit ammeter.

Thus, the magnetizing force $I W_{1}$ of the primary winding has the same value for all standard sizes of over current protections and changes in each of the zones of variation of the monitored currents also within the same limits (1:4). If the transformer core is not saturated, then in proportion to the magnetizing force, the magnetic flux, and, consequently, the secondary winding electromotive force will also change within the same limits.

For an ideal transformer, the secondary winding active and reactive resistance is equal to zero in comparison with the load resistance, and also the losses due to hysteresis and eddy currents in the core are equal to zero, the equivalent circuit and the corresponding vector diagrams will have a simplified form, shown in Fig. 2.

In the transformer mode (Fig. $2 a$ ), the dependence of the output voltage $U_{2}$ on the input (controlled) current $I_{1} U_{2}=f\left(I_{1}\right)$ is ambiguous and not linear, since it is simultaneously influenced by the load current of the secondary winding $I_{2}=g_{2} U_{2}$, and the magnetizing current $I \mu$, which, in turn, depends on the magnetic circuit magnetic resistance. Therefore, the transformer in this mode is not suitable for use as a current sensor.

In this regard, a transformer current sensor looks more favourable (Fig. 2b), operating in the idle mode (transreactor mode $g_{2}=0$ ) [15]. Phase-shifting transformers used in phase-sensitive current protection devices EM (FPDs), developed at the Latvian Agricultural Academy under the guidance of Doctor of Technical Sciences A.O. Grundulis [16; 17]. In the absence of a secondary current, the current $I_{1}$ becomes completely magnetizing; therefore, it quickly transfers the magnetic circuit to the saturation mode. In this case, not only is the linearity of the dependence of the output voltage $U 2$ of the current sensor on the input current value $I_{1}$ sharply violated, but the output voltage shape is also distorted. A way out of this situation is to install a non-magnetic gap (usually a few millimetres) in the path of closing the magnetic flux. For the purpose of universality of the threshold and logical parts of overcurrent protection units of various standard versions, the protection operation voltage $U_{2 \mathrm{C}}$ should be the same not only for all protection units' standard versions, but also unchanged for all settings of the operation current $I_{1 \mathrm{y}}$ within the current working zones of each standard version. Changing the operation settings within the protection units' operating currents in the case of using transreactors as current sensors can only be made by changing the value of the non-magnetic gap. It is inconvenient to carry out this in real 
operating conditions, and due to the non-magnetic gap small value, it is technically difficult to establish the size of the gap with the required accuracy.

a)
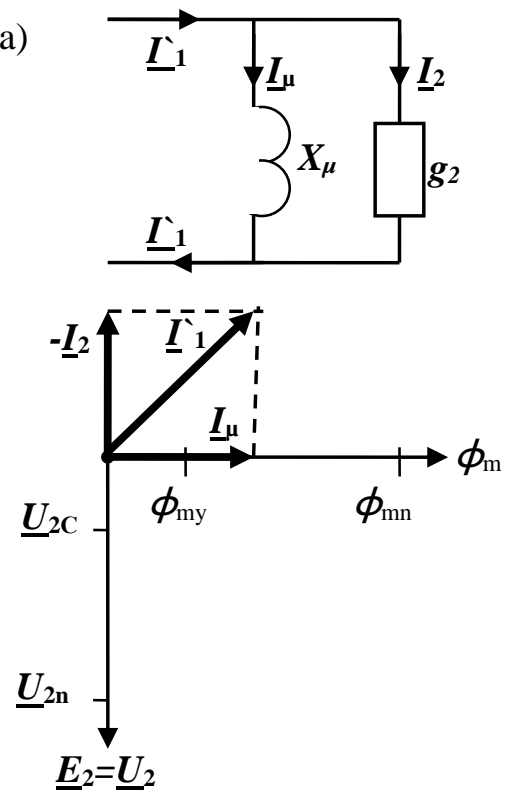

b)
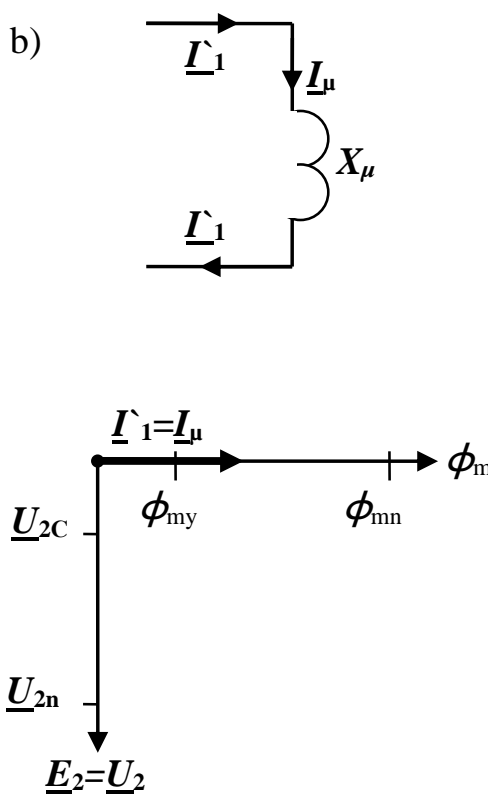

c)
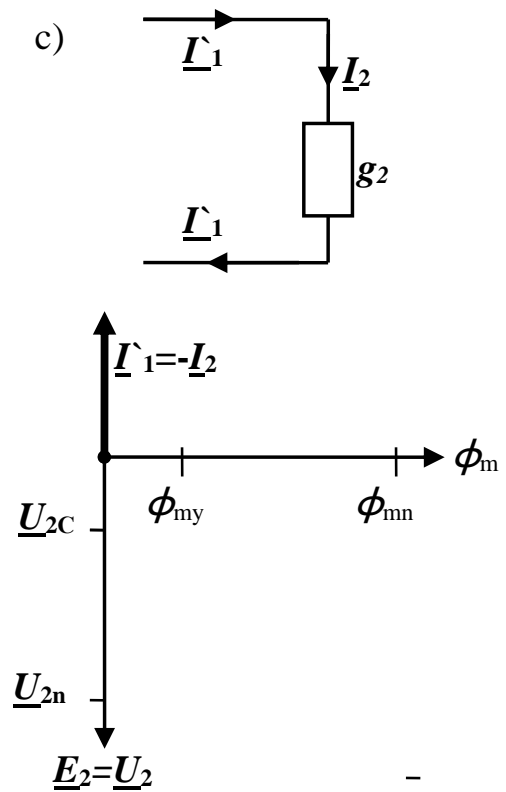

Fig. 2. Equivalent circuits and vector diagrams of ideal, consequently included in the circuit of the measured current: $\mathrm{a}$ - transformer; $\mathrm{b}$ - transreactor; $\mathrm{c}$ - current transformer

The widest possibilities are possessed by transformer current sensors operating in the current transformer mode (Fig. 2c), the secondary winding of which operates in a mode close to a short circuit $\left(r_{2}=0\right)$. In the short-circuit mode, if the magnetic circuit does not have an air gap, the magnetizing current is $1 \ldots 3 \%$ of the current in the primary winding [18]. Therefore, with a very small error, it can be assumed that the magnetizing forces of the primary and secondary windings are balanced

$$
I_{1} W_{1}=I_{2} W_{2} \text {. }
$$

From where

$$
I_{1}=g_{2} U_{2} W_{2} / W_{1},
$$

where $I_{1}$ and $I_{2}$-currents flowing respectively through the primary winding of the current transformer and the secondary winding, closed to the load resistance, A; $W_{1}$ and $W_{2}$ - number of turns, respectively, of the primary and secondary windings of the current transformer;

$g_{2}=1 / R_{2}-$ load conductivity, $\mathrm{Cm}$;

$r_{2}-$ load resistance, $\mathrm{Ohm}$;

$U_{2}-$ voltage across the load resistance, $\mathrm{V}$.

The EM protective shutdown occurs when the voltage $U_{2}$ coming from the secondary winding output to the potential input of the logical part of the protection device reaches the value $U_{2 \mathrm{C}}$ equal to the reference voltage of the threshold element of the logical part. The current $I_{1}$ of the electric motor corresponding to this voltage is the operating current (setting current $I_{y}$ ) of the protection device. Thus,

$$
I_{y}=g_{2} U_{2 \mathrm{C}} W_{2} / W_{1} \text {. }
$$

In principle, changing the setting current $I_{y}$ can be carried out by changing any value on the right side of the resulting equation.

First, it is the number of turns of the primary winding $W_{1}$. From the expression it follows that with its increase, the setting current decreases. However, the number of the primary winding turns does not exceed several units, and the wire cross-section corresponds to the current of the protected electric motor power circuit. Therefore, by changing the number of the primary winding turns, as shown above, it is possible to change the setting with a discreteness of 2: 1 only to adjust to the range of monitored currents 
for a particular size of the current protection unit, but not to fine-tune the current of the protected motor current, lying within this range.

Secondly, this is the voltage at the output of the secondary winding $U_{2 \mathrm{C}}$, at which the protection device is triggered. This can be done by setting the threshold element of the logical part of the protection device. It is known that the voltage (EMF) and the magnetic flux in the steel of the transformer core are related to each other at the current constant frequency by an unambiguous relationship [19]

$$
E_{2}=4.44 f W_{2} \Phi_{m},
$$

where $f$-current frequency, $\mathrm{Hz}$; $\Phi_{m}$ - amplitude value of magnetic flux, $\mathrm{Wb}$.

Since the magnetic flux for each specific core is limited due to the steel saturation, its maximum value and, therefore, the maximum turn voltage must correspond to the inrush current of the highest EM, to which the protection can be adjusted. Then, in the nominal EM mode, the magnetic flux in the core of the current sensor will be $k_{\mathrm{i}}$ times less than the maximum. That is, the core even for the most powerful protected EM will be underutilized in the nominal mode, taking into account fluctuations, depending on the type of EM, the multiplicity of the starting current by 5 ... 7.5 times.

Underutilization of the core will increase even more when protecting the smallest EM from the setting range of this particular current protection device. Underutilization will increase exactly as many times as the current at the upper limit of the setting range is greater than the current at the lower limit.

Thirdly, this is the number of turns of the secondary winding. Changing the current setting of the protection equipped with a current transformer by changing the number of the secondary winding turns, provided that the voltage $U_{2 \mathrm{C}}$ is kept constant, although in principle it is possible, but impractical, since simultaneously with the change in the number of turns it would be necessary to change the turn voltage value in the opposite direction, and hence the magnetic flux. Technically, such a change is unreasonably difficult to implement. In addition, the very change in the turn number can only be done discretely in steps. Serious inconvenience if you want to increase the number of steps will cause a large number of taps from the current transformer secondary winding and the presence of a multi-position switch.

Fourthly, it is the conductivity $g_{2}$, which bypasses the current transformer secondary winding. With a change in conductivity, as follows from expression (3), a directly proportional change in the setting current occurs. Technically, such a change can be carried out using variable resistors (rheostats). The multiplicity of setting changes can reach ten or even more times. In this case, in the entire range, the voltage at the secondary winding output, equal to the threshold element input voltage, and, consequently, the magnetic flux will remain constant.

The problem here lies only in the fact that in multiphase current protection devices, the change in conductivity in the circuit of each CC should be made strictly synchronously. In addition, to change the conductivity, a special designed rheostat with a linear scale relative to the conductivity should be used. Then, since the setpoint current is directly proportional to the conductivity, the setpoint scale will also be linear. However, the technical implementation of such a condition is practically not feasible.

Therefore, we have proposed a method of stepwise change in the total conductivity connected to the secondary winding output of current transformers by a set of parallel connected resistors in a certain way, which conductivity values change in a geometric progression with a progression ratio equal to two (Fig. 3).

The number $r$ of the setting current generator binary bits, equal to the number of resistors and toggle switches that switch resistors, determines the number $N$ steps of setting the current protection operation setting within the zone $\Delta I y$ of changing the station current settings

$$
N=2^{r}-1 .
$$

It was shown above that the dial scale is uniform over the entire range of setting changes, and, therefore, the division price of the dial

$$
C_{D}=\Delta I_{\mathrm{y}} /(N-1)=\Delta I_{\mathrm{y}} /\left(2^{r}-1\right) .
$$

In addition, for the convenience of translating the setting number into the setting current, it is desirable to expand this zone to a value at which the price of one division of the setting current generator would be convenient for multiplying or dividing by a number. 
The maximum relative error $\delta I_{y \cdot \max }$ of the current protection setting for the motor current will be observed in stations with double overlapping of the setting zone at the minimum current setting $I_{y \cdot m i n}$, i.e. at the very beginning of the setting change zone

$$
\delta I_{y \cdot \max }=0.5 C_{D} / I_{\mathrm{y} \cdot \min }=0.5\left(I_{\mathrm{y} \cdot \max }-I_{\mathrm{y} \cdot \min }\right) /(N-1) I_{\mathrm{y} \cdot \min }=0.5\left(I_{\mathrm{y} \cdot \max }-I_{\mathrm{y} \cdot \min }\right) /\left(2^{r}-1\right) I_{\mathrm{y} \cdot \min } .
$$

Taking into account that with double overlapping of the setting zone $I_{\mathrm{y} \cdot \max }=4 I_{\mathrm{y} \cdot \min }$

$$
\delta I_{\mathrm{y} \cdot \max }=0,5\left(4 I_{\mathrm{y} \cdot \min }-I_{\mathrm{y} \cdot \min }\right) /\left(2^{r}-1\right) I_{\mathrm{y} \cdot \min }=1.5 /\left(2^{r}-1\right) .
$$

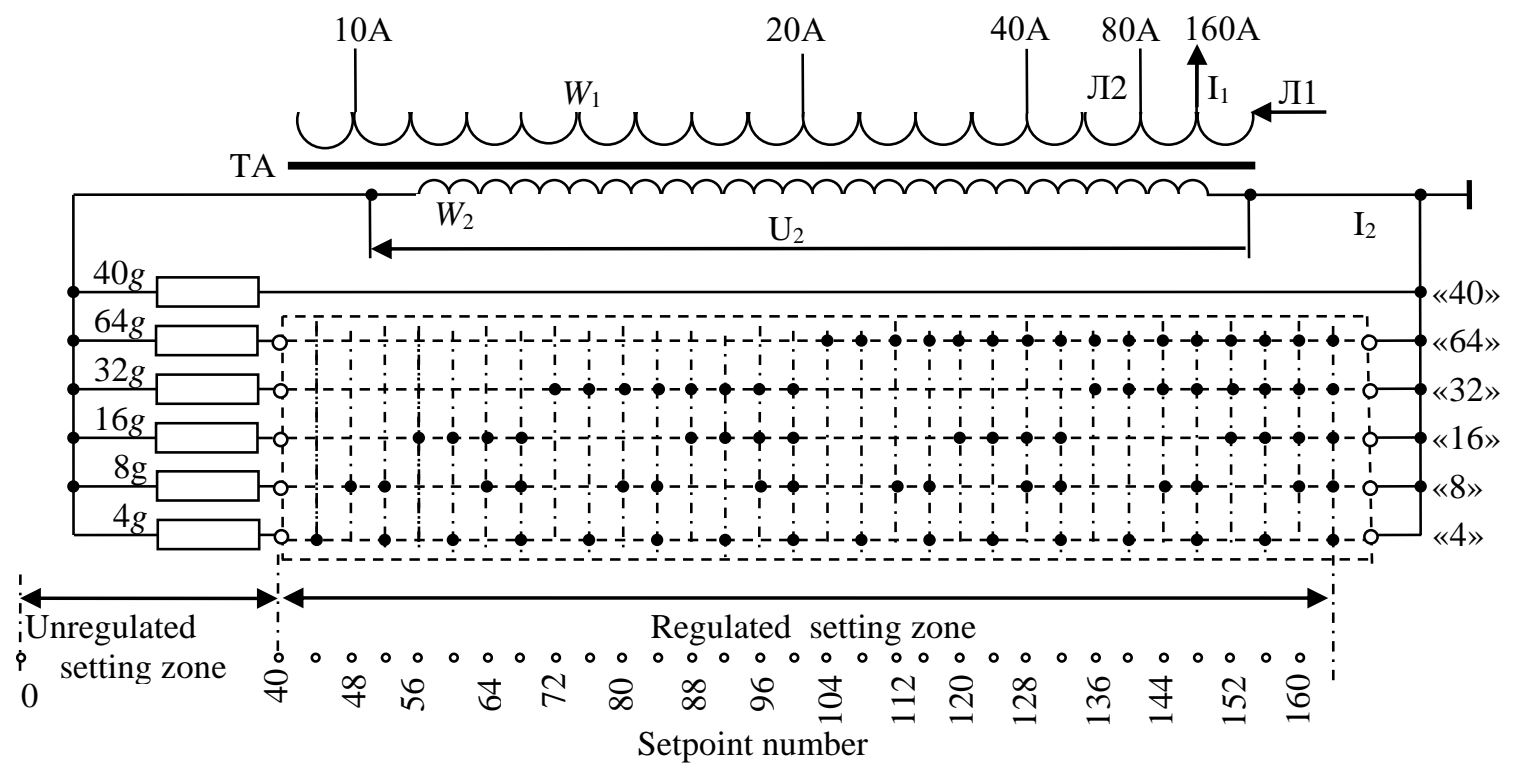

Fig. 3. Scheme of changing the zones of rated currents and diagram of changing the current settings

From where

$$
r=\log _{2}\left(1.5 / \delta I_{y \cdot \max }+1\right)=\left(\ln \left(1.5 / \delta I_{y \cdot \max }+1\right)\right) / \ln 2 .
$$

Taking the maximum relative error of setting the current setting equal to 0.05 , we get

$$
r=(\ln (1.5 / 0.05+1)) / \ln 2=4.95 .
$$

Thus, a five-bit current setpoint adjuster may well provide sufficient accuracy for setting the setpoint. In this case, in fact, the error of setting the setpoint at the beginning of the zone of setting the setpoints (maximum error)

$$
\delta I_{\mathrm{y} \text { max }}=1.5 /\left(2^{r}-1\right)=1.5 /\left(2^{5}-1\right)=0.048,
$$

and the actual minimum error (in the zone of maximum setting currents) -

$$
\delta I_{\mathrm{y} \cdot \min }=0.5\left(4 I_{\mathrm{y} \cdot \min }-I_{\mathrm{y} \cdot \min }\right) /\left(2^{r}-1\right) 4 I_{\mathrm{y} \cdot \min }=0.375 /\left(2^{r}-1\right)=0.012 .
$$

\section{Research results}

On the basis of the design diagram theoretical substantiation of the current protection measuring and mastering unit, a station standard-size range was developed for the electric pumping unit automatic control equipped with overcurrent protection units for rated currents from $160 \mathrm{~A}\left(W_{1}=1\right)$ to $5 \mathrm{~A}$ $\left(W_{1}=32\right)[20]$.

Current sensors operating in the current transformer mode for all types of protection units had the same twisted magnetic core made of transformer steel with a diameter of $50 \mathrm{~mm}$ and a cross section of $1 \mathrm{~cm}^{2}$. Since the current transformer secondary winding was connected to the input of the threshold element of the logical part of the current protection through $R C$ - filters of forward currents and currents of negative phase sequences [21;22], which require increased voltage for their accurate functioning, the secondary winding number of turns was taken equal to 3200. In this case, with a magnetizing force of the primary winding of 160 amperes of turns, the current in the secondary winding was $0.05 \mathrm{~A}$. This 
current, closing through a set of conductivities $160 \mathrm{~g}(\mathrm{~g}=0.0025 \mathrm{~cm}$ or $r=400 \mathrm{ohms})$, creates at the filter input voltage $20 \mathrm{~V}$.

The setting current for all station standard versions was determined by dividing the setting number, set by a switch set of positions of the setting current generator (see Fig. 3), by the turn number of the primary winding $W 1$.

In total, 2000 such station copies were made, which showed a high efficiency of protection of submersible pump electric motors not only from current overload, but also from current asymmetry, as well as from reducing the current consumed by the electric motor in the event of a shaft break or "dry running" with water insufficient flow rate in the well. Many station copies, having worked for more than 25 years, are in operation to this day.

\section{Conclusions}

Thus, it is shown that the transformer current sensor operating in the current transformer mode, in comparison with the transreactor, has more stable parameters, a linear input-output characteristic, as well as the same level of magnetic flux, both for all standard versions of current protection, as well as in the variation settings entire range within a specific standard version. It is proposed to change the protection operation setting of each standard version within the range from 25 to $100 \%$ of its rated current by discretely changing the secondary winding load conductivity of the current transformer.

\section{References}

[1] Мусин А.М. Электропривод сельскохозяйственных машин и агрегатов. (Electric drive of agricultural machines and units) - М.: Агропромиздат (Agropromizdat), 1985. - 239 p. (In Russian)

[2] Iegorov O., Iegorova O., Miroshnyk O., Savchenko O. Improving the accuracy of determining the parameters of induction motors in transient starting modes. Energetika. 2020. T. 66. Nr. 1. pp. 15-23.

[3] Электронасосы ЭЦВ6-16-110Г-У5, ЭЦВ6-16-75Г-У5/Паспорт и инструкция по эксплуатации. (Electric pumps ETSV6-16-110G-U5, ETSV6-16-75G-U5/Passport and operating instructions) - Оренбург: Госагропром РСФСР, Росагропромэнерго, Оренбургагропромэнерго, (Orenburg: Gosagroprom RSFSR, Rosagropromenergo, Orenburgagropromenergo), 1991. - 12 p. (In Russian)

[4] Gizatullin F.A., Khakimyanov M.I., Khusainov F.F., Shafikov I.N. Analysis of losses in the cable line of well submersible electric motor // International Conference on Industrial Engineering, Applications and Manufacturing, ICIEAM Proceedings. - 2017. -

DOI: 10.1109/ICIEAM.2017.8076285.

[5] ButorinV.A. Bench-scale tests aimed at finding rate and accelera-tionof wear determining service life of thrust bearing in submersible electric motor /V.A.Butorin, I.B.Tsarev, R.T.Guseynov // Lecture Notes In Mechanical Engineering. 2020, pp. 1089-1095.

[6] Iegorov O., Iegorova O., Kundenko M., Milenin A. The influence of the phase angle between the rotor magnetic axis and the stator winding current vector on the synchronous reluctance motor efficiency. Proceedings of the IEEE International Conference on Modern Electrical and Energy Systems (MEES), 2019. pp. 62-65.

[7] Baghaee H. R., Mirsalim M., Gharehpetian G. B. Power calculation using RBF neural networks to improve power sharing of hierarchical control scheme in multi-DER microgrids. IEEE Journal of Emerging and Selected Topics in Power Electronics. 2016. Vol. 4. No. 4. pp. 1217-1225.

[8] Система управления системы САУНА. Станция управления ШЭП 5802. Техническое описание, инструкция по эксплуатации, паспорт. ВПО «Союзпреобразователь». (SAUNA system control system. Control station SHEP 5802. Technical description, operating instructions, passport. VPO «Soyuzpreobrazovatel») Прежевальский электротехнический завод, г. Пржевальск, Иссык-Кульская обл. типография (Prezhevalsk Electrotechnical Plant, Przhevalsk, Issyk-Kul region printing house), 1984, 1443. 21 p., (In Russian)

[9] ТУ16-536.042-76 Устройство комплектное «Каскад» Устройство комплектное «Каскад» для автоматического управления и защиты скважинных насосов с погружными электродвигателями. (TU16-536.042-76 Complete device "Kaskad" Complete device "Kaskad" 
for automatic control and protection of borehole pumps with submersible electric motors) Каталог - Электротехника ССCР. - М.: Информэлектро (Catalog - Electrical engineering of the USSR. - M .: Informelectro), 1983, 8 p. (In Russian)

[10] Novozhilov N.G. Digital algorithm for fast detecting and identifying the asymmetry of voltages in three-phase electric grids of mechanical engineering facilities/N.G. Novozhilov, O.B. Shonin,S.B. Kryltcov // IOP: Materials Science and Engineering. - 2017. - V.177. - pp. 253-258.

[11]Petko V., Petrov A., Rakhimzhanova I., Shakhov V., Ushakov Y., Fomin M. Permissible voltage asymmetry for asynchronous motor operating in non-nominal operating conditions Contents of Proceedings of 19th International Scientific Conference Engineering For Rural Development. Volume 19. May 20-22, 2020, Jelgava, LATVIA. pp. 897-905.

[12] Yegorov A., Yegorova O. Analysis of transient processes in an asynchronous motor as part of a complex load. Multidisciplinary Scientific Edition 'WORLD SCIENCE'. 2017. Vol. 1. No. 10. Pp. $12-15$.

[13] Тлеуов А.X. Разработка и обоснование методики выбора защиты электроприводов с. х. машин от перегрузок (Development and substantiation of the methodology for choosing the protection of electric drives of agricultural machines from overloads): Дис. Канд. техн. наук. - M. (dissertation of the candidate of technical sciences - M.), 1981. - 211 p. (In Russian)

[14] ГОСТ 6827-76 Электрооборудование и приёмники электрической энергии. Ряд номинальных токов. (GOST 6827-76 Electrical equipment and receivers of electrical energy. A number of rated currents. [online] [09.02.2021] Available at: http://vsegost.com/Catalog/40/40742.shtml (In Russian)

[15] Трансреактор - трансформатор тока с магнитопроводом, имеющим воздушный зазор. (Transreactor is a current transformer with a magnetic circuit having an air gap. [online] [01.02.2021] Available at: https://studopedia.su/9_85111_transreaktor---transformator-toka-smagnitoprovodom-imeyushchim-vozdushniy-zazor.html. (In Russian)

[16] А.С. 928513 СССР, МКИ Н 02 Н 7/09. Устройство для защиты погружных электродвигателей от повреждения (A.S. 928513 USSR, MKI N 02 N 7/09. Device for protecting submersible motors from damage )/A.О. Грундулис, А.А. Шнидерс, П.Э. Лешевиц (СССР). Заявитель Ордена Трудового Красного Знамени сельскохозяйственная академия (Applicant for the Order of the Red Banner of Labor Agricultural Academy). published. 15.05.1982. - 8 p. (In Russian)

[17]Грундулис А.О. Теоретическое исследование кольцевого фазочувствительного устройства защиты электродвигателя (Theoretical study of an annular phase-sensitive motor protection device) // Труды института: Электромеханизация и автоматизация стационарных процессов в сельском хозяйстве/ЛСХА (Proceedings of the Institute: Electromechanization and automation of stationary processes in agriculture/LSHA). - 1987. Release, 238. pp. 4-18. (In Russian)

[18] Сукманов В.И. Электрические машины и аппараты (Electrical machines and apparatus). - M.: Колос (М.: Kolos), 2001. - pp. 85-93. (In Russian)

[19]Пиотровский Л.М. Электрические машины (Electrical machines) // Издание второе переработанное/Государственное энергетическое издательство Л. М. (Second revised edition/State energy publishing house L.M.) 1952. - 188 p. (In Russian)

[20] Станция для автоматического управления электронасосными агрегатами «СИГНАЛ», ТУ 1690 ТИДЖ656.325.001ТУ (Station for automatic control of electric pump units «SIGNAL», TU 1690 TIDZH656.325.001TU). - Оренбург, завод «Инвертор» (Orenburg, plant “Invertor") - 1995. -38 p. (In Russian)

[21] А. с. 1319149 СССР, МКИ Н 02 7/08. Устройство для защиты трёхфазного электродвигателя от анормальных режимов (А. s. 1319149 USSR, MKI N 02 7/08 Device for protecting a threephase electric motor from abnormal conditions)/В.Г. Петько (USSR). Заявитель Оренбургский сельскохозяйственный институт (Applicant Orenburg Agricultural Institute), published 22.02.1987. - 4 p. (In Russian)

[22] А. с. 1120441 Устройство для защиты трёхфазного электродвигателя от анормальных режимов (A. s. 1120441 Device for protecting a three-phase electric motor from abnormal conditions)/В.Г. Петько (USSR). Заявитель Оренбургский Ордена Трудового Красного Знамени сельскохозяйственный институт (Applicant Orenburg Order of the Red Banner of Labor Agricultural Institute), published 22.06.1984. - 4 p. (In Russian) 